\title{
Assetization: A technoscientific or financial phenomenon?
}

\section{Philipp Golka}

Leiden University, Netherlands

\begin{abstract}
Finance and financialization have dominated scholarship on capitalism and society for the past decade. Although scholars noted early on that the expansion of finance relies on the creation (and trade) of new financial assets, assets and assetization have been a blind spot as scholarship continued to focus on financial markets (Langley, 2020). This, however, is currently about to change as a number of landmark publications have been published in the past months that point toward growing momentum in the field of asset and assetization research. In this short essay, I review Kean Birch and Fabian Muniesa's edited collection, Assetization: Turning Things into Assets in Technoscientific Capitalism, which is of central importance to said momentum, and put it into dialogue with some of the other recent publications on this topic.
\end{abstract}

\section{Keywords}

Assets, assetization, financialization, valuation studies, political economy

Kean Birch and Fabian Muniesa (eds.), Assetization: Turning Things into Assets in Technoscientific Capitalism, Cambridge, MA, MIT Press, 2020, 338 pp., \$40.00 (pbk), ISBN 978-0-262-53917-3

According to Birch and Muniesa (2020), our contemporary times are defined by a form of technoscientific capitalism manifested in the increasing power of technological firms, practices, and innovations. The central argument put forth in the introduction to their book is that the "dominant form that technoscientific capitalism affords is not the commodity but the asset" (p. 1, emphasis in original), rendering capital investment rather than market speculation the prevailing form of financial engagement. This distinction is foregrounded in their definition of an asset as "something that can be owned or controlled, traded, and capitalized as a revenue stream" (p. 2). Due to this nature, the asset form implies a specific orientation in those who own or control assets: the goal is not to make a profit from selling 
assets as commodities - rather, the idea is "to get a durable economic rent from them" (ibid.). As rent refers to the "extraction of value through ownership and control" and "usually entails limiting access to it" (ibid.), the key point is, as Muniesa stressed during the book launch event on December 7, 2020, that assets are "made to keep". Assets need not be financial objects. As colloquial uses of the word (e.g., someone being an asset to a team) suggest, assets can be many things, such as people, skills, property rights, or - as the empirical chapters in the book observe - wheat seeds, sunlit rooftops, or homeless people as they change their behavior.

At first sight, the future-oriented, return-yielding notion of assets resembles that of capital. Besides the editors' intention to circumvent theory-laden controversies attached to the notion of capital, the key distinction between the two is the constructivist-processual conception of assets. In contrast to more substantivist notions of the value of capital, value is external to assets and constructed through practices of valuation. Needless to say, there are similarly constructivist notions of capital (not least in Muniesa et al., 2017) that somewhat dissolve the distinction between both terms. Still, the asset perspective indicates a different focus as it foregrounds the empirical processes that make things valuable and rent-bearing. With that out of the way, we can now turn to the core of the book: the process of "how things are turned into assets'.

According to Birch and Muniesa, assetization is a process of "narrative transformation" (p. 18) centered on practices of valuation that turn things into (valuable) assets. Transforming something into an asset is a "techno-scientific process" in which the boundaries, characteristics, and worth of an asset are established while social actors are "reframed, altered and conceptualized anew" (ibid.). Thus, the study of assetization is not limited to a specific school of thought. Rather, its focus is strongly empirical and defined by "the conjunction of gray zones and unsettled issues" that the book seeks to make explicit ( $p$. 15). This makes assetization accessible to various theoretical traditions, although its intellectual lineage particularly in science and technology studies (STS) and valuation studies remains clearly visible throughout the book.

What sets assets apart is that they are, in contrast to commodities, made to keep. This means they are usually legal objects that enable different modes of ownership and control, such as the ability to define forms of use or limit access. In many cases, these properties allow rentiership (i.e., the extraction of financial rents through monopoly control). As these rents often accrue in the future, one key aspect of assetization is the construction of value in the present through forward-looking financial tools, such as the calculation of net present value by time-discounting expected future cashflows. In contrast to commodities, where value accrues at the point of exchange, asset valuation is an unfolding social process that usually entails struggles over appropriate valuation devices and underlying assumptions (such as discount rates) and thereby extends into the future. Assets are valuable and investable primarily due to the future revenues they bear, and not so much because of their current market value.

As a result, investors and investment rather than traders, merchants, and market exchange define their financial properties. This points to both the commonalities and differences between assetization and financialization. Assetization is, as the editors note, closely linked to what Eve Chiapello (2015) has described as the 'financialization of valuation' - i.e., the performance of specific tools of financial valuation that reconfigure objects from the perspective of investors. Thus, the increasing proliferation of financialized valuation enables and critically facilitates assetization. Yet, assetization per se does not necessarily render objects tradable on financial markets. While financial markets require assets (to be traded as commodities), assets - and hence assetization - do not necessarily need financial markets.

The editors' argument that assetization processes are distinct empirical phenomena in 
their own right is convincing. But (how) does assetization matter? This is where we get to the ten empirical sections of the book, which provide rich case studies that describe how knowledge, infrastructure, nature, and publics are turned into assets. Without exception, these contributions feature analyses of capitalist transformations that are equally timely and significant. For example, Kang observes how intellectual property rights are, as patent portfolios, turned into assets solely based on their legal solidity and probability of winning disputes. As a result, the very basis of financial capitalism - private law - is itself turned into an asset. Likewise, Beauvisage and Mellet provide an almost archeological unearthing of how layer upon layer of technology transform personal data into 'datassets', and thus convincingly link assetization to current debates on 'platform capitalism' (Langley and Leyshon, 2017). In line with the STS tradition, attention is also paid to objects that are seemingly far away from capitalist transformations. For example, Veit Braun's contribution on the "capitalism of varieties" provides a lucid analysis of wheat seeds as assets (for breeders), commodities (when ground and sold as flour), and challenges for assetization (when kept by farmers for farmbreeding). The travel of wheat seeds shows a key distinction between assets and commodities: that assets can be "let go of" and still return to their owners, rather than making quits in exchange (p. 219). At the same time, the travel of wheat seeds points us to the fact that the goods themselves have a say in their assetization, which leads to specific arrangements and forms of contestation.

\section{Assetization between asset management and asset economy}

By foregrounding the making of rent-bearing assets, the book contributes to addressing a 'blindspot' in the existing political economy literature. As Paul Langley (2020: 383, 384) has recently pointed out, political economy has typically been most concerned with "speculative logics and credit-debt relations", and with this has come a set of analytical limitations linked to a "narrow focus on speculation and asset price bubbles". Assetization provides a vital corrective. Because assets are made to extract rent through ownership and control (rather than profits from market exchange), they are problematic not because of amorphous objects such as 'the market' or 'finance'. Rather, what is at stake in assetization is a valorization that benefits first and foremost those who control assets. Here, the editors concur with Chiapello (2015) in noting that assetization often entails a 'colonization' of its objects, resulting in a somewhat alienated view of their value as well as an exploitative relation that spans into the future. However, there are three issues that limit the book's contribution in this regard.

First, the book gives away some of its diagnostic potential by locating the 'technoscientific process' of assetization in a technoscientific capitalism. Is the (capitalist) world really this technoscientific? If, as the editors argue, the asset form has become the dominant capitalist form, then it is unfortunate that the book pays so little attention to the meso- and macro-level drivers and implications of assetization. Granted, the empirical contributions provide different contexts, but we still miss a coherent analysis of how extant actors and power relations shape, reinforce, or transform assetization processes. Particularly because assets have a special relationship with financial actors and expertise, I was surprised not to find any empirical studies on assetization in 'high' finance in the book. If assetization indeed dominates contemporary capitalism, then the obvious question is how this relates to "asset manager capitalism' (Braun, forthcoming). Given that recent research (e.g., Petry, 2020) has shown that financial intermediaries are not just brokers, but critically shape financial realities both upand down- stream in the financial chain, we would expect a generative relationship between the rise of asset managers and the asset form. 
This is a twofold missed opportunity, for it would also have been interesting to understand how the rise of asset management affects assetization 'on the ground'. For example, Daniela Gabor (2021) argues that investors and asset managers have become "epistemic guardians" in defining green financial products, while confining the role of states in the Global South to making and "de-risking" infrastructure assets to be sold on financial markets. Here, the assetization perspective has great potential as a means of investigating these transformations at the micro level. The same is true as we miss a link between assetization and corporate governance. It has recently been argued that the empowerment of managers was more central to the transformation of firms than the ascendancy of shareholders and the market for corporate governance (Knafo and Dutta, 2020). As the dominance of asset managers "shareholders without any skin in the game" (Braun, forthcoming) - seems to exacerbate this development, numerous questions regarding the assetization of corporate governance are opened up that seem worth exploring further.

Asset management aside, the book circumnavigates another elephant in the room: housing and asset-based welfare. As Adkins, Cooper, and Konings (2020) argue in their new book, The Asset Economy, rampant asset price inflation (along with wage stagnation) is one of the most important political economic developments of recent times. While initially designed to support the middle classes, asset-based welfare has now created new fault lines between asset owners and 'churners'. Seeing that Adkins et al. warn us of using 'rentiership' to understand the asset economy, assetization might serve here as a powerful tool to uncover micro-level dynamics, especially since the relation between rents and asset values is anything but straightforward in housing markets. Take, for example, the Berlin housing market, where a recent 'rent ceiling' temporarily reduced rents on property without affecting property values or investors' appetite for housing assets. Analyzing such seemingly paradoxical effects from an assetization perspective would therefore make an important contribution to the literature (and the need for such analysis very much persists, even as the German constitutional court nullified said Berlin rent ceiling in April 2021).

Second, the concept of assetization as well as the book's empirical analyses remain on a somewhat descriptive rather than explanatory level. This means that questions of agency, power, and enabling conditions remain relatively undertheorized. Here, the book implicitly carries the legacy of actor-network theory, in which "there is no such thing as a social context in which actors are embedded" (Mützel, 2009: 877). As a result, we observe that people and things are enrolled into calculative devices and valuation practices, but we gain (with some exceptions) only little clarity on the role of the to-be-assetized in the process.

This is evidenced, for example, in Williams' excellent chapter on Social Impact Bonds (SIBs), which are public service delivery contracts that pay variable returns to investors based on the delivery of quantified 'social outcomes'. In contrast to the financialization scholarship on this topic, which tends to treat SIBs as the new frontier of an ever-expanding realm of finance, Williams makes an important counterpoint by stressing their persistent marginality, which he locates in the enormous amount of valuation work that is required to set up SIB contracts in a context of value plurality. While government officials want to see social outcomes established by randomized control trials (RCTs), investors see those as a source of uncertainty that hinders their attempts to performance-manage the contracted delivery organizations (Birch and Muniesa, 2020: 299). But although this notion of "valuation struggles" (p. 296) shows that things cannot be turned into assets "by proclamation" (Seabrooke, 2010), we still lack clarity on the structural conditions that do or do not make the SIB proposition acceptable and attractive. Indeed, a comparative perspective shows that valuation work alone cannot explain SIB dissemination. Although proponents' 
activities are similar in the UK and Germany, only the UK has seen a (limited) rise of SIBS because the entrenchment of a 'Treasury view' in social policy under Gordon Brown made SIBs somewhat attractive to policymakers (Golka, 2019). Structural and institutional contexts therefore matter for assetization processes, and it would be important to understand in more detail how this is so.

Third, for a book dedicated to 'how things are turned into assets', I would have found a schematic description of assetization processes helpful - both to gain more clarity of the nature of the process, as well as out of a practical consideration to help empirical researchers. Since Chiapello's notion of financialized valuation takes a central role in assetization, it would have been interesting to see how assetization compares with or departs from her conceptualization of financialization as a three-staged process of "problematization", "tangibilization", and "financial structuring" (Chiapello, 2020: 85). A more systematic analysis of the sequential nature of assetization processes could also be helpful in terms of identifying its underlying causal mechanisms (Gross, 2009).

Such a schematic description need not be limited to sequential properties, but could also investigate relational features. For example, Brett Christophers (2015) has provided an analysis of four financial 'value models' that describe how income is created from financial engagements; how do these compare to the extraction of rent from assets? Indeed, the case of asset managers seems to be a particularly interesting one in this regard, as the different value models along the financial chain point to a layering of assetization. As asset managers charge, according to Braun (forthcoming), performance-independent fees from investors (such as pension funds), to them, the financial products themselves are the valuable assets. By contrast, to investors, the firms and the expected future revenues represented in the financial products make the assets valuable. Thus, a more systematic conception of assetization along financial chains would have been useful.

\section{Conclusion: Closing the blind spot}

Despite these criticisms, Assetization is a highly valuable contribution and an exception in the world of edited volumes. Not only is the notion of assetization important, timely, well-crafted, and relatable to a number of scholarly perspectives; the empirical contributions add significantly to the development of the concept. This is most obvious in the fact that the book really is a page-turner that invites a cover-to-cover reading. The concept of assetization remains clearly visible throughout the book without becoming repetitive as each chapter adds new empirical contexts, different actors, and some variegation of practices and processes. At the same time, the contributions are of such high quality that they are equally informative as stand-alone articles.

Assets do not need financial markets, and it is understandable that, to make this point, the editors locate the empirical focus of the book far away from the glitzy towers (and posh home offices) of high finance. However, there is a special relationship between finance and assets, and therefore we urgently need to investigate how things are turned into assets not in a technoscientific, but in a financialized capitalism. To do so, we may need to bring in other research from sociology and political economy to clarify the role of institutions, situations, networks, agency, and power in the making of assets. By no means should this displace the STS-inspired valuation perspective: the book has made its contribution abundantly clear. Instead, we should aim for a symbiotic relationship in the shared quest to close our collective blind spots regarding assets and assetization. Therefore, none of the points of critique mentioned above weaken the merit of this important contribution. Rather, the editors and 
contributing authors were able to develop a notion of assetization that is both robust and open enough to guide future research. This is why we can be confident that this book will prove to be a real asset for the scholarly community

\section{References}

Adkins, L., Cooper, M. and Konings, M. (2020) The Asset Economy: Property Ownership and the New Logic of Inequality. Cambridge: Polity.

Birch, K. and Muniesa, F. (2020) Assetization: Turning Things into Assets in Technoscientific Capitalism. Cambridge, MA: MIT Press.

Braun, B. (forthcoming) Asset manager capitalism as a corporate governance regime. In: Hacker, J.S., Hertel-Fernandez, A., Pierson, P. and Thelen, K. (eds.) American Political Economy: Institutions, Interests, and Inequalities. Cambridge: Cambridge University Press.

Chiapello, E. (2015) Financialisation of valuation. Human Studies, 38(1): 13-35.

Chiapello, E. (2019) Financialization as a socio-technical process. In: Mader, M., Mertens, D. and van der Zwan, N. (eds.) The Routledge International Handbook of Financialization. London: Routledge, 81-91.

Christophers, B. (2015) Value models: Finance, risk, and political economy. Finance and Society, 1(2): 1-22.

Gabor, D. (2021) The Wall Street consensus. Development and Change, https://doi.org/10.1111/dech. 12645

Golka, P. (2019) Financialization as Welfare: Social Impact Investing and British Social Policy, 19972016. Cham: Springer.

Gross, N. (2009) A pragmatist theory of social mechanisms. American Sociological Review, 74(3): 35879.

Knafo, S. and Dutta, S.J. (2020) The myth of the shareholder revolution and the financialization of the firm. Review of International Political Economy, 27(3): 476-99.

Langley, P. (2020) Assets and assetization in financialized capitalism. Review of International Political Economy, https://doi.org/10.1080/09692290.2020.1830828

Langley, P. and Leyshon, A. (2017) Platform capitalism: The intermediation and capitalization of digital economic circulation. Finance and Society, 3(1): 11-31.

Muniesa, F., Liliana, D., Ortiz, H., Pina-Stranger, Á., Paterson, F., Bourgoin A., Ehrenstein, V., Juven, P.-A., Pontille D., Saraç-Lesavre, B. and Yon, G. (eds.) (2017) Capitalization: A Cultural Guide. Paris: Presses des Mines.

Mützel, S. (2009) Networks as culturally constituted processes: A comparison of relational sociology and actor-network theory. Current Sociology, 57(6): 871-87.

Petry, J. (2020) From national marketplaces to global providers of financial infrastructures: Exchanges, infrastructures and structural power in global finance. New Political Economy, https://doi.org/ 10.1080/13563467.2020.1782368

Seabrooke, L. (2010) Everyday legitimacy and institutional change. In: Gofas, A. and Hay, C. (eds.) The Role of Ideas in Political Analysis: A Portrait of Contemporary Debates. London: Routledge, 78-93. 